\title{
Pharmacognosy \\ Phytochemical screening and biological assays of ethanolic leaf extract of Senna rugosa
}

\author{
Letícia Figueiredo Cunha ${ }^{1}$, Camila Marques Costa $^{2}$, Poliana Ribeiro Barroso ${ }^{1,6,7}$, Kelly Cristina Kato ${ }^{1}$, \\ Fabrício de Oliveira ${ }^{1}$, Carlos Victor Mendonça Filho ${ }^{3}$, Cristiane Fernanda Fuzer Grael ${ }^{1}$, Luiz Elídio Gregório ${ }^{4}$, \\ Fernanda Fraga Campos ${ }^{5}$, Patrícia Machado de Oliveira $^{2}$, Danilo Bretas de Oliveira ${ }^{5}$, \\ Fernando Armini Ruela ${ }^{2} \&$ Helen Rodrigues Martins ${ }^{1}$
}

\begin{abstract}
Senna rugosa (Fabaceae) is a common specie of the Brazilian territory, especially in the Cerrado biome. It is widely used in the popular medicine although not yet adequately investigated as to its phytoconstituents and pharmacological activities. In this study, the preliminary phytochemical analysis of ethanolic leaf extract of $S$. rugosa was performed and its cytotoxicity, antitumoral and antimicrobial activities (antibacterial, antifungal, anti-Trypanosoma and anti-Leishmania) were evaluated. The crude extract was analyzed in HPLC-DAD and fractions were also characterized using GC-MS and ESI-MS techniques. Results indicate phenolic compounds majority presence, including flavonol, anthraquinone and anthrones derivatives. Relative antimicrobial activities were detected against Staphylococcus aureus, Pseudomonas aeruginosa, Candida famata, Candida krusei and Candida tropicalis. As well as, a weak anti-trypanosomatids activity against M2269 strain and BH46 strain of Leishmania sp. A relative antitumoral activity was also identified but in counterpoint were also observed a toxicity in fibroblast cells (L929). Phytochemically, results provide evidence that phenolic compounds in S. rugosa leaves might be the responsible for its antimicrobial activity and cell toxicity inferred in our research.
\end{abstract}

Key words: biological activity, phenolic compounds, phytochemical profile, Senna rugosa.

\section{Resumo}

Senna rugosa (Fabaceae) é uma espécie comum do território brasileiro, especialmente no Cerrado. É amplamente utilizado na medicina popular, embora ainda não tenha sido investigada quanto aos seus fitoconstituintes e atividades farmacológicas. Neste estudo, foram realizadas as análises fitoquímicas preliminares do extrato etanólico de folhas de S. rugosa e sua citotoxicidade, atividade antitumoral e antimicrobiana (antibacteriana, antifúngica, antiTrypanosoma e anti-Leishmania). O extrato bruto foi analisado em HPLC-DAD e as frações foram caracterizadas usando técnicas de GC-MS e ESI-MS. Os resultados indicam a presença majoritária de compostos fenólicos, incluindo flavonóis, antraquinonas e derivados de antronas. Atividades antimicrobianas foram detectadas contra as espécies Staphylococcus aureus, Pseudomonas aeruginosa, Candida famata, Candida krusei e Candida tropicalis. Além disso, uma fraca atividade anti-tripanossomatídeos contra as cepas M2269 e BH46 de Leishmania sp. Uma atividade antitumoral foi identificada, porém também foi observada uma toxicidade sobre células de fibroblastos (L929). Fitoquimicamente, os resultados fornecem evidências de que compostos fenólicos nas folhas de $S$. rugosa podem ser os responsáveis pela sua atividade antimicrobiana e pela toxicidade celular observada em nosso estudo. Palavras-chave: atividade biológica, compostos fenólicos, perfil fitoquímico, Senna rugosa.

\footnotetext{
${ }^{1}$ Federal University of the Jequitinhonha and Mucuri Valleys (UFVJM), Dep. Pharmacy, Campus JK, Rod. MGT-367, km 583, n 5000, Alto do Jacuba, 39100-000, Diamantina, MG, Brazil.

${ }^{2}$ Federal University of the Jequitinhonha and Mucuri Valleys (UFVJM), Dep. Chemistry, Campus JK, Rod. MGT-367, km 583, nº 5000, Alto da Jacuba, 39100-000, Diamantina, MG, Brazil.

${ }^{3}$ Federal University of the Jequitinhonha and Mucuri Valleys (UFVJM), Dep. Biology, Campus JK, Rod. MGT-367, km 583, n 5000, Alto da Jacuba, 39100-000, Diamantina, MG, Brazil.

${ }^{4}$ Federal University of San Paulo (UNIFESP), Lab. Environmental, Chemical and Pharmaceutical Sciences, Unidade José Alencar, R. São Nicolau 210, Center, 09913-030, Diadema, SP, Brazil.

${ }^{5}$ Federal University of the Jequitinhonha and Mucuri Valleys (UFVJM), Dep. Medicine, Campus JK, Rod. MGT-367, km 583, nº 5000, Alto da Jacuba, 39100-000, Diamantina, MG, Brazil.

${ }^{6}$ ORCID: $<$ https://orcid.org/0000-0001-9031-8722>

${ }^{7}$ Author for correspondence: poliana.barroso@ict.ufvjm.edu.br
} 


\section{Introduction}

Plants have an important role in the treatment of diseases and remain as the core of the traditional medicine systems in different countries (Newman \& Cragg 2016). Brazil is a huge source of potentially useful plants in the medical standpoint. The genus Senna (Fabaceae) is widespread in Brazilian ecosystems, with some greatly appreciated species and widely used as ornamental plants for the beauty of its flowers. Senna rugosa (G. Don) Irwin $\&$ Barneby (1982: 35) is a medium-sized shrub that reaches up to 1.6 meters height (Dantas \& Silva 2013). It can be easily identified by the massive amount of characteristic bright yellow flowers during the winter. It occurs in all regions of the Brazilian territory (BFG 2018) and is known for its therapeutic properties. In the popular medicine, $S$. rugosa has been reported as an anthelmintic remedy and a snakebites antidote (Rodrigues \& Carvalho 2001). Like other species belonging to the genus, it is quite possible that there are many other activities yet to be associated with S. rugosa. The genus Senna is known to produce various classes of aromatic compounds, e.g., quinones (Alemayehu et al. 1989), anthraquinones (Abegaz et al. 1994), naphthopyrones (Barbosa et al. 2004), triterpenoids (Li et al. 2012) and flavonoids (Baez et al. 1999). Natural anthraquinones are responsible for the cathartic effect commonly associated with species of the genus Senna (Dave \& Ledwani 2012). However, S. rugosa was not adequately investigated as to its phytoconstituents and pharmacological activities.

Tropical diseases and bacterial infections are a major medical problem in global public health since different types of pathogens are encountered widespread in several countries. The current treatment of several of these diseases has large limitations. For instance, Leishmaniasis and Chagas disease are between the most important tropical neglected diseases affecting millions of people worldwide (WHO 2017, 2018a; Sundar \& Chakravarty 2015). Unfortunately, the conventional therapies for this both diseases are toxic, has registry of resistance and low efficacy in some clinical forms, for example to chronic phase of Chagas disease and to diffuse cutaneous leishmaniasis (Griensven et al. 2016; Hendrickx et al. 2018; Kratz 2019).

Additionally, bacterial and fungal resistance to antimicrobial agents is too common, mainly in nosocomial and immunosuppressed patients, being responsible for significant morbidity, mortality and the increase in the treatment cost (Oliveira \& Silva 2008; Silva 2010; Nakamura et al. 2013). Cancer represents another important and complex disease that affects populations worldwide (WHO $2018 \mathrm{~b}$ ). The treatment is performed by surgery, radiotherapy, chemotherapy or their combination. In general, chemotherapy is the most used alternative, but there have been limitations such as development of drug resistance, serious toxic effects and low efficacy in certain clinical forms (Luisi et al. 2006). Consequently, the discovery and development of new chemotherapeutic agents more effective and less toxic for these pathologies has received a great attention nowadays (Kunz \& Brook 2010; Casellas 2011; Ventola 2015).

Use of plant extract and other natural compounds might represent an attractive option for discovery of new alternative therapeutic. Several studies have been conducted by different team and confirm the pharmacological potential the of plantderived products as new drugs (Almagboul et al. 1985; Artizzu et al. 1995; Bhalodia \& Shukla 2011; Thavamani et al. 2014). In this context, this study aim was to evaluate the phytochemical profile and its cytotoxicity and antiparasitic and antitumoral activities of the Senna rugosa ethanolic leaf extract. Furthermore, the crude extract was analyzed in High Performance Liquid Chromatography-Diode Array Detector Method (HPLC-DAD) and the initial characterization of the fractions by Gas Chromatography-Mass Spectrometry (GC-MS) and Electrospray Ionization Mass Spectrometry (ESI-MS) methods were also performed.

\section{Materials and Methods}

Chemicals and reagents

All the chemicals used were analytical grade reagents. Mercury (II) chloride, bismuth carbonate, iodine, metallic magnesium, cupric sulphate, sodium citrate, anhydrous sodium carbonate, sodium hydroxide, ammonium hydroxide, gelatin, sodium hydroxide, ferric chloride, lead acetate, rutin, emodin, aloe-emodin and Folin - Ciocalteu's phenol reagent were provided by Sigma-Aldrich ${ }^{\circledR}$ (St Louis, MO, USA). Concentrated hydrochloric acid, sulfuric acid and gallic acid were purchased by Dinâmica ${ }^{\circledR}$ (Diadema, São Paulo, Brazil). Silica gel 60G70-230 mesh and Aluminum TLC Plates SIL G/UV ${ }_{254}$ were acquired from Macherey-Nagel ${ }^{\circledR}$ (GmbH \& Co.KG, Düren, Germany). Glacial acetic acid, potassium iodide, $n$-Hexane, ethyl 
acetate, ethanol (96 $\left.{ }^{\circ} \mathrm{GL}\right)$ and methanol were provided by Synth ${ }^{\circledR}$ (Diadema, São Paulo, Brazil). Acetonitrile was provided by Panreac ${ }^{\circledR}$ (Castellar del Vallès, Barcelona, Spain).

Plant material and sample preparation Senna rugosa species was identified and authenticated by the Ph.D. Carlos Victor Mendonça Filho, of the Department of Botany, UFVJM, Brazil. The leaves of $S$. rugosa were harvested at the University Campus of Federal University of the Jequitinhonha and Mucuri Valleys (UFVJM), Campus JK, Alto do Jacuba, Diamantina, Minas Gerais, Brazil on 07.IV.2015 in the Cerrado field with appropriate Brazilian authorization to access the genetic heritage $\left(\mathrm{n}^{\circ} 010832 / 2014-9\right)$. The voucher specimen (HDJF 4236) was deposited in this institution herbarium. Leaves of $S$. rugosa were dried in an oven with air circulation $\left(\right.$ Solab $^{\circledR}$ SL102, São Paulo, Brazil) for 30 days at $39{ }^{\circ} \mathrm{C}$. After dried, the leaves were ground to powder using a knife mill (Solab ${ }^{\circledR}$ SL32, São Paulo, Brazil). The powder (100 g) was added to $1 \mathrm{~L}$ of solvent (ethanol $96^{\circ} \mathrm{GL}$ ) and macerated for 7 days and this process was repeated 3 times. Thereafter the mixture was filtered, and the solvent was evaporated $\left(39{ }^{\circ} \mathrm{C}\right)$ using a rotative evaporator (Fisatom ${ }^{\circledR}$ 804, São Paulo, Brazil). The authorization of access to genetic resources (Process Registration Number: AACD7CF) was obtained from National System for Management of Genetic Heritage and Associated Traditional Knowledge (SISGEN).

\section{Fractionation}

Ethanolic extract of Senna rugosa leaves was fractionated with $n$-hexane: ethyl acetate with an increasing polarity gradient, starting with 100\% $n$-hexane up to $100 \%$ ethyl acetate. Subsequently, the eluent was exchanged to ethyl acetate: methanol increasing polarity gradient, starting with $100 \%$ ethyl acetate up to $100 \%$ methanol. A $1 \mathrm{~g}$ sample of the ethanolic extract was fractionated in eight fractions of $n$-hexane: ethyl acetate with the following ratios $(\mathrm{v} / \mathrm{v}): 1: 0\left(1^{\text {st }}\right.$ and $2^{\text {nd }}$ fraction $)$, 95:05 ( $3^{\text {rd }}$ fraction), 9:1 ( $4^{\text {th }}$ and $5^{\text {th }}$ fraction), 85:15 ( $6^{\text {th }}$ fraction), 65:35 ( $7^{\text {th }}$ fraction $), 0: 1$ ( $8^{\text {th }}$ fraction $)$, using a silica gel $60 \mathrm{G}$ packed chromatography column. From all mixtures of ethyl acetate: methanol, only the methanol $100 \%$ was able to elute the remaining constituents of the column ( $9^{\text {th }}$ fraction). Following elution, the resultant fractions collected in test tubes were qualitatively evaluated using the thin-layer chromatography (TLC) performed on silica gel $\mathrm{GF}_{256}$.

Plant samples phytochemical analysis Phytochemical analysis was performed according to Simões et al. (2007). The specific chemical reactions assays were carried out on the crude extract and on the fractions samples in order to determine secondary metabolites presence such as tannins, phenols, steroids, triterpenes, saponins, flavonoids, alkaloids and anthraquinones.

\section{Total phenolic content}

Total Phenolic Content (TPC) was determined by the Folin-Ciocalteau method (Singleton et al. 1965) with some modifications. Senna rugosa crude leaf extract and the eighth and the ninth fraction were analyzed. Diluted samples $(255 \mu 1$ of $300 \mu \mathrm{g} / \mathrm{mL}$ extract solution) were mixed with $15 \mu \mathrm{l}$ of Folin-Ciocalteu reagent (1:10 v/v diluted in water) and incubated for $3 \mathrm{~min}$. It was added $30 \mu \mathrm{l}$ sodium carbonate $(1.0 \mathrm{~N})$ and the mixture was incubated for $2 \mathrm{~h}$ at room temperature. The absorbance was measured at $765 \mathrm{~nm}$ (SpectraMax Paradigm Multi-Mode Microplate Reader UV/ Visible Spectrophotometer - Molecular Devices ${ }^{\circledR}$ Sunnyvale, CA, USA) and TPC was estimated based on a Gallic acid standard curve and expressed as milligrams of Gallic acid equivalents (GAE) $\mathrm{g}^{-1}$. The result was reported as a mean value and standard deviation for three distinct assays.

\section{HPLC-DAD analysis}

Chromatographic analysis of crude extract was carried out using a Phenomenex ${ }^{\circledR}$ LUNA-C18(2) column $(4.6 \mathrm{~mm} \times 150 \mathrm{~mm}, 3 \mu \mathrm{m})$ (Shimadzu ${ }^{\circledR}$, Kyoto, Japan) LC system consisting of quaternary pump LC-20AT, degasser DGU20A5, the column oven CTO-20A, autosampler SIL-20ACHT with DAD detector SPD-M20A. The detection wavelength was set at $270 \mathrm{~nm}$. The flow rate and injection volumes were $0.8 \mathrm{~mL} /$ min and $10 \mu \mathrm{L}$, respectively. The mobile phase was A-ultrapure water (Direct- $\mathrm{Q}^{\circledR} /$ Millipore $^{\circledR}$ ) and B-acetonitrile (Panreac ${ }^{\circledR}$, Castellar del Vallès, Barcelona, Spain), using gradient elution: $0-5$ min, $10 \% \mathrm{~B}$; 5-45 min, $10-100 \% \mathrm{~B}$; 45-50 min, $100 \%$ B ; 50-52 min, $100-10 \%$ B; 52-60 min, $10 \%$ B. The mobile phase was filtered through a 0.2 $\mu \mathrm{m}$ GHP membrane disc filter (47 mm diameter, Pall Corporation ${ }^{\circledR}$ Nova York, USA) and then denaturized ultrasonically prior to use. The column oven was set at $35^{\circ} \mathrm{C}$. 
Gas chromatography-mass spectrometry (GC-MS) analysis

Apolar fractions were injected into the GC (Perkin Elmer CLARUS 680 GC (Waltham ${ }^{\circledR}$, MA, USA) with helium as carrier gas and a GC coated column with 5\% diphenyl 95\% dimethyl polysiloxane, $0.25 \mathrm{~mm} \times 30 \mathrm{~m}$ (ELITE-5) and coupled to a spectrometer CLARUS 600T (Waltham ${ }^{\circledR}$, MA, USA). The conditions were as follows: temperature programming from 60-240 ${ }^{\circ} \mathrm{C}$ (rate $3 / \mathrm{min}$ ) holding at $240{ }^{\circ} \mathrm{C}$ for $15 \mathrm{~min}$. The injection temperature was $220{ }^{\circ} \mathrm{C}$ and injection mode was split (ratio 50). The total flow was automatically adjusted, and the column flow was $0.6 \mathrm{~mL} / \mathrm{min}$. The temperature source was 190 ${ }^{\circ} \mathrm{C}$ and solvent cut time was $2 \mathrm{~min}$. For the mass spectrometer in positive mode $\left(\mathrm{EI}^{+}\right)$, the start time was $2 \mathrm{~min}$, end time was $75 \mathrm{~min}$, scan time was $0.2 \mathrm{~s}$, and start $\mathrm{m} / \mathrm{z}$ ratio was 50 while end $\mathrm{m} / \mathrm{z}$ ratio was 400 (Adams 2007). The mass spectrum was also equipped with a computer mass spectra data bank NIST v1.0.2.2.

\section{Electrospray ionization mass} spectrometry (ESI-MS) analysis

As no chromatographic separation was performed in the HPLC, the chemical profile of the fractions rich in acidic compounds $\left(8^{\text {th }}\right.$ e $\left.9^{\text {th }}\right)$ was achieved by direct infusion in the ESI-MS (Shimadzu ${ }^{\circledR}$ LCMS-2020, Kyoto, Japan) set to negative mode. The identities of the main peaks in the phenolic fraction were suggested based on information reported in references (Gill \& Morgan 2001; Bastos et al. 2007; Sang et al. 2007; Falcão et al. 2010; Navarre et al. 2011; Hamed et al. 2014; Spindola et al. 2014; Schmeda-Hirschmann et al. 2015; El Sayed et al. 2016).

\section{Biological assays}

Antibacterial activity assay

Four different species of bacteria were used from American Type Culture Collection (ATCCRockville $^{\circledR}$ MD, USA): Staphylococcus aureus (ATCC 29313), Salmonella typhimurium (ATCC 14028), Klebsiella oxytoca (ATCC 49131) and Pseudomonas aeruginosa (ATCC 27853). The microdilution assay was carried by the guidelines of the National Committee for Clinical and Laboratory Standards Institute (CLSI 2012) using MuellerHinton medium (Himedia ${ }^{\circledR}$ Mumbai, India) to determine the minimal inhibitory concentration (MIC). All assays were performed in triplicate.
Serial dilutions of plants extracts were prepared in sterile polystyrene 96 -wells to range 1,000 to 125 $\mu \mathrm{g} / \mathrm{mL}$ dissolved in dimethyl sulfoxide $0.125 \%$ (DMSO - Sigma-Aldrich ${ }^{\circledR}$ Sto Louis, MO, USA). The final concentration of bacterial suspension was adjusted to $5 \times 10^{5}$ colony-forming unit $/ \mathrm{mL}$ in supplemented $\mathrm{MH}$ broth in the final volume of 100 $\mu \mathrm{L}$. Media was used without the addition of extract or solvent for a growth and sterility control. As a control for the toxicity of the solvent, a culture was incubated with DMSO in the same concentration used in extract preparation. Conventional antibiotic chloramphenicol (Sigma-Aldrich ${ }^{\circledR}$ Sto Louis, MO, USA) was used as standard drug and after plates preparation and $24 \mathrm{~h}$ of incubation at $37{ }^{\circ} \mathrm{C}, 30$ $\mu \mathrm{l}$ of resazurin solution $0.01 \%$ (Sigma-Aldrich ${ }^{\circledR}$ Sto Louis, MO, USA) was added to each well, incubated for $4 \mathrm{~h}$ at $37^{\circ} \mathrm{C}$, and assessed for color development. A change from blue to pink indicates the resazurin reduction and therefore bacterial growth. The MIC was defined as the lowest drug concentration that completely inhibits the growth of the organism in microdilution wells where no color change occurred.

The nature of the activity was also determined by adding $10 \mu \mathrm{L}$ aliquots of all preparations which did not show visible growth during microdilution assay (MIC) in $10 \mathrm{~mL}$ of saline buffer $0.09 \%$. After homogenization, $100 \mu \mathrm{L}$ this preparation was spread in BHI agar medium plates. These plates were incubated at $37^{\circ} \mathrm{C}$ for $24 \mathrm{~h}$. All controls were also evaluated in this assay. For the absence of bacterial growth, the extracts were considered with bactericidal activity and the presence of growth were considered with bacteriostatic activity.

Antifungal activity assay

Minimum inhibitory concentration (MIC) was determined by broth microdilution method on according to Clinical and Laboratory Standards Institute (CLSI) recommendations (CLSI 2002a, b). All tests were conducted in triplicate in three different experiments and involved reference strains from the ATCC (Rockville ${ }^{\circledR}$ MD, USA): Candida albicans (ATCC 90028); Candida famata (ATCC 62894); Candida krusei (ATCC 34135); Candida tropicalis (ATCC 28707); Aspergillus niger (ATCC 10535) and Penicillium expansum (ATCC 1117). Candida species were maintained on Sabouraud dextrose agar (Himedia ${ }^{\circledR}$, Mumbai, India) and incubated at $37^{\circ} \mathrm{C}$ for $48 \mathrm{~h}$ (CLSI 2002a). Filamentous fungi were harvested on solid YPD medium (Himedia ${ }^{\circledR}$, Mumbai, India) 
at $28{ }^{\circ} \mathrm{C}$ for seven days (CLSI 2002b). Inoculum suspensions were prepared by spectrophotometric method corresponding to approximately $5.0 \times 10^{2}$ to $2.5 \times 10^{3} \mathrm{CFU} / \mathrm{mL}$ and $0.4 \times 10^{4}$ to $5.0 \times 10^{4}$ $\mathrm{CFU} / \mathrm{mL}$ respectively. Yeast cells in the exponential phase were collected aseptically with a sterile loop and resuspended in a tube containing $5 \mathrm{~mL}$ of sterile saline. The suspensions were diluted in Roswell Park Memorial Institute (RPMI) medium (Sigma-Aldrich ${ }^{\circledR}$ Sto Louis, MO, USA) containing L-glutamine and buffered to $\mathrm{pH} 7$ with $0.165 \mathrm{M}$ Morpholino Propanesulfonic Acid (MOPS - SigmaAldrich $^{\circledR}$ Sto Louis, MO, USA). The extract was dissolved in DMSO (Sigma-Aldrich ${ }^{\circledR}$ Sto Louis, MO, USA) and subsequently, serial dilutions were prepared using RPMI as the diluent and tested at concentrations ranging of 1,000 to $125 \mu \mathrm{g} / \mathrm{mL}$. For a growth and sterility control, media was used without the addition of extract or solvent. As a control for the toxicity of the solvent, a culture was incubated with DMSO. Amphotericin B $4 \mu \mathrm{g} / \mathrm{mL}$ (Sigma-Aldrich ${ }^{\circledR}$ Sto Louis, MO, USA) was utilized as the positive antifungal control. The inoculum of each fungal strain was added, and the plates were incubated at $37^{\circ} \mathrm{C}$ for $48 \mathrm{~h}$ for Candida species and $28^{\circ} \mathrm{C}$ for $72 \mathrm{~h}$ for filamentous fungi. Each test was performed in triplicate. The MIC was defined as the lowest drug concentration that prevented this color change.

Anti-trypanosomatids activity assays

Leishmania (Leishmania) amazonensis (MHOM/BR/73/M2269) and Leishmania (Leishmania) infantum (MHOM/BR/1070/BH46) was maintained at $26^{\circ} \mathrm{C}$ in Liver Infusion Tryptose medium (LIT - Camargo 1964), supplemented with $10 \%$ fetal bovine serum (Gibco Invitrogen ${ }^{\circledR}$ Grand Island, NY, USA) and the promastigotes forms were used for all experiments. The anti-leishmanial activity against promastigotes was determined in flat-bottomed 96-well plastic tissue-cultured plates. Promastigotes were counted in a Neubauer hemocytometer and for the assay $1 \times 10^{7}$ parasites/ $\mathrm{mL}$ were seeded with different ethanolic extracts in the concentration range of 1,000 to $125 \mu \mathrm{g} /$ $\mathrm{mL}$. Commercial drug amphotericin B $(5 \mu \mathrm{g} / \mathrm{mL}$ - Sigma ${ }^{\circledR}$ Sto Louis, MO, USA) was used as the standard drug and positive control. The following controls were also used DMSO and Ethanol as solvents controls and pure culture as viability control. The plates were incubated at $26^{\circ} \mathrm{C}$ for $72 \mathrm{~h}$ and the viability of parasites was assayed colorimetrically by the mitochondrial oxidation of
MTT (3-[4,5-dimethylthiazol-2-y1]-2,5diphenyltetrazolium bromide) as described by Mosmann (1983). The optical density was detected at 560 $\mathrm{nm}$ with a spectrophotometer detection platform (Spectra Max ${ }^{\circledR}$ Paradigm - Molecular Devices, Sunnyvale, CA, USA) and correlated with the number of living promastigotes. Control wells without any sample were established as $100 \%$ viable. Inhibitory concentration $50\left(\mathrm{IC}_{50}\right)$ was determined by the logarithmic regression analysis method (Sebaugh 2011).

Two Trypanosoma cruzi strains were used for evaluating the anti-Trypanosoma activity: $\mathrm{Y}$ and Colombian strains which are considered prototypes of partial susceptibility and resistant to benznidazole respectively (Filardi \& Brener 1987). Epimastigotes were harvested axenically in LIT at $28{ }^{\circ} \mathrm{C}$, being supplemented with $10 \%$ fetal bovine serum (Gibco Invitrogen ${ }^{\circledR}$ Grand Island, NY, USA) and used in all experiments in the stationary phase. The assays were performed in the same conditions described above for antileishmanial activity, but Benznidazole (BZ) was used as standard drug in $75 \mu \mathrm{g} / \mathrm{mL}$ concentration (Muelas-Serrano et al. 2000).

\section{Antitumoral activity assay}

Human breast cancer cell lines MDA-MB-231 were obtained from ATCC (LGC Promochem ${ }^{\circledR}$ Rockville, MD, USA) and used to determine the antitumoral activity of the crude extract. The MDA-MB-231 were maintained in Dulbecco's modified Eagle medium (DMEM - Sigma-Aldrich ${ }^{\circledR}$ Sto Louis, MO, USA) supplemented with $10 \%$ fetal bovine serum and antibiotics $(100 \mathrm{mg} / \mathrm{mL}$ of streptomycin and $100 \mathrm{unit} / \mathrm{mL}$ of $\mathrm{G}$ penicillin, Sigma-Aldrich ${ }^{\circledR}$ St. Louis, USA). Cells were maintained in the exponential growth phase at 37 ${ }^{\circ} \mathrm{C}$ in a humidified incubator with an atmosphere of $5 \% \mathrm{CO}_{2}$ and submitted periodical peal. The cells were plated $1.5 \times 10^{5}$ cells/well in a 96-well flat-bottom plates and allowed to adhere for $24 \mathrm{~h}$. Paclitaxel 6 ng/mL (Quiral Química ${ }^{\circledR}$, Juiz de Fora, Brazil) was used as a standard drug (PXT). Cells without a test compound were used as a viability control, DMSO used as a solvent toxicity control while the condition with only medium was used as blank. After incubation for $72 \mathrm{~h}$ with the crude extract in the concentration range of 1,000 to 7.8 $\mu \mathrm{g} / \mathrm{mL}$, the cell viability was measured by the MTT assay as previously described by Mosmann (1983). The relative growth rate was calculated to evaluate the extract antitumoral activity. Inhibitory 
concentration $50\left(\mathrm{IC}_{50}\right)$ was determined by the method of logarithmic regression analysis of data obtained. All analysis was performed in triplicate, and the average data were reported as the results.

\section{Cytotoxicity cellular assay}

Mouse fibroblast cells (L929) were maintained at RPMI (Sigma-Aldrich ${ }^{\circledR}$ Sto Louis, MO, USA) using the same conditions of supplementation above. For cell viability assay, $1 \times 10^{5}$ cells/well were seeded into 96-well plates followed by the addition of the Senna rugosa ethanolic leaf extract tested in the concentration ranging of 1,000 to $7.8 \mu \mathrm{g} / \mathrm{mL}$ prepared in cell culture media. Cell viability was measured by MTT assay as previously described by Mosmann (1983) and the $50 \%$ cytotoxic concentration $\left(\mathrm{CC}_{50}\right)$ was calculated. Cells without a test compound were used as a viability control, DMSO was used as a solvent toxicity control and only the medium served as the blank. The cadmium chloride $\left(\mathrm{CdCl}_{2}\right)(200$ nM - Quiral Química ${ }^{\circledR}$, São Pedro, Juiz de Fora, Brazil) was used as death control.

\section{Statistical analysis}

The statistical analyses were performed using Graph Pad Prism 3.0 software. Results were expressed as the mean \pm standard deviation of triplicate samples from three independent assays and were analyzed using the analysis of variance (ANOVA one way) with Bonferroni multiple comparison adjustment for parametric data. Significant differences from the control group were determined by Dunnett's test for non-parametric data, with $\mathrm{p}<0.05$ as the significance criterion. The $\mathrm{EC}_{50}$ values were calculated using sigmoid doseresponse curves in Graph Pad Prism.

\section{Results and Discussion}

Preliminary phytochemical analysis and thin-layer chromatography of the plant extract and fractions

After ethanolic extract preparation $5.7349 \mathrm{~g}$ of crude leaf extract of Senna rugosa were obtained corresponding to $5.73 \%$ of yield. Preliminary phytochemical analysis results showed that $S$. rugosa leaves contain flavonoids, tannins, triterpenes and anthraquinones. TLC analysis showed that $5^{\text {th }}, 6^{\text {th }}$ and $7^{\text {th }}$ fractions are mixtures of pigments (chlorophylls and carotenoids). Using $n$-hexane as eluent in TLC; $1^{\text {st }}, 2^{\text {nd }}, 3^{\text {rd }}$ and $4^{\text {th }}$ fractions have low retention factor (Rf) values: $0.77 ; 0.72 ; 0.7$ and 0.54 respectively, suggesting the presence of apolar compounds such as leaf waxes, fatty alcohols and other similar organic compounds. Rf high values for the dark-brownish residues obtained $\left(8^{\text {th }}\right.$ and $9^{\text {th }}$ fractions) and immediate solubility in alkaline solutions revealing an acid character of these constituents being consistent with phenolic compounds.

Anthraquinone species have already been described in roots of $S$. rugosa (Barbosa et al. 2004). Anthraquinones are secondary metabolites very common in Fabaceae family to which this species belongs (Bruneton 2001; Sakulpanich \& Gritsanapan 2008; Sahu et al. 2014), confirming our data achieved by phytochemicals tests and ESI -MS results.

Triterpenes and steroids were also found in ethanolic extracts of the leaves and of the seeds of S. rugosa (Farias et al. 2010). Other studies also identified the presence of flavonoids in the leaves of S. rugosa (Eberhardt 2012). In the present study, the result of phytochemical screening of the ethanolic leaf extract of $S$. rugosa was also identified tannins. Moreover, Farias et al. (2010) failed to detect such a metabolite class in the $S$. rugosa aqueous seed extract. However, several studies have documented the possibility of identifying different chemical compositions in the extract from the same plant species (Azevedo et al. 2014), since a yield or result of extraction depends on the solvent with varying polarity, the composition of the sample, $\mathrm{pH}$, extraction time and temperature. In addition, plant parts used on different research are not always the same and what could also justify the divergence of results is due to the genetic and the ontogeny variations among individuals or in environmental conditions that may alter the metabolism.

\section{Total phenolic content}

The content of phenolic compounds in $S$. rugosa ethanolic leaf extract and in the $8^{\text {th }}$ and $9^{\text {th }}$ fractions with the acid character was determined through a linear Gallic acid standard curve $\left(\mathrm{y}=0.003968 \mathrm{x}+0.486683 ; \mathrm{r}^{2}=0.9924\right)$. The total phenolic content of the $8^{\text {th }}$ fraction was $325.87 \pm 12 \mathrm{mg} \mathrm{GAE} / \mathrm{g}$ and of the $9^{\text {th }}$ fraction was $152.4 \pm 5.94 \mathrm{mg} \mathrm{GAE} / \mathrm{g}$ (Tab. 1). Phenolic compounds detected by the Folin-Ciocalteau method can be classified into simple phenols and polyphenols. Simple phenols include phenolic acids, coumarins among other molecules. Nevertheless, polyphenols cover the flavonoids, stilbenes, lignans and tannins (Balasundram et al. 2006; Tsao 2010). Anthraquinones can be simple phenols or 
Table 1 - Total phenolic content of Senna rugosa leaf ethanolic extract.

\begin{tabular}{lc}
\hline Sample & $\begin{array}{c}\text { Phenolic compounds } \\
\text { (mg GAE.g } \text { of extract) }^{-1}\end{array}$ \\
\hline Ethanolic extract & $43.87 \pm 2.69$ \\
$8^{\circ}$ fraction & $325.8 \pm 12$ \\
$9^{\circ}$ fraction & $152.4 \pm 5.94$ \\
\hline
\end{tabular}

$\mathrm{GAE}=$ Gallic Acid Equivalent

polyphenols, depending on its molecular structure and is considered one of the major plant phenolic pigments (Mohammed 2016). Simple phenols and the polyphenols present in plants are subjects of increasing scientific interest due to their potential biological action, particularly in pharmacological terms and possible beneficial effects on human health. Polyphenols are secondary metabolites generally involved in defense against aggression by pathogens or ultraviolet radiation (Beckman 2000). Additionally, polyphenols are some of the principal compounds related to the benefits of a diet rich in different plant parts, tea and wine, due to their antioxidant properties. The values obtained in Folin-Ciocalteau method achieved in this work are in accordance with three classes of metabolites detected in the preliminary phytochemical analysis (anthraquinones, flavonoids and tannins).

\section{Analysis of crude extract by HPLC-DAD}

The HPLC-DAD results revealed the presence of a major peak in the crude extract, with time retention at $17.22 \mathrm{~min}$ (Fig. 1). Aiming to identify the major secondary metabolite of this extract, some

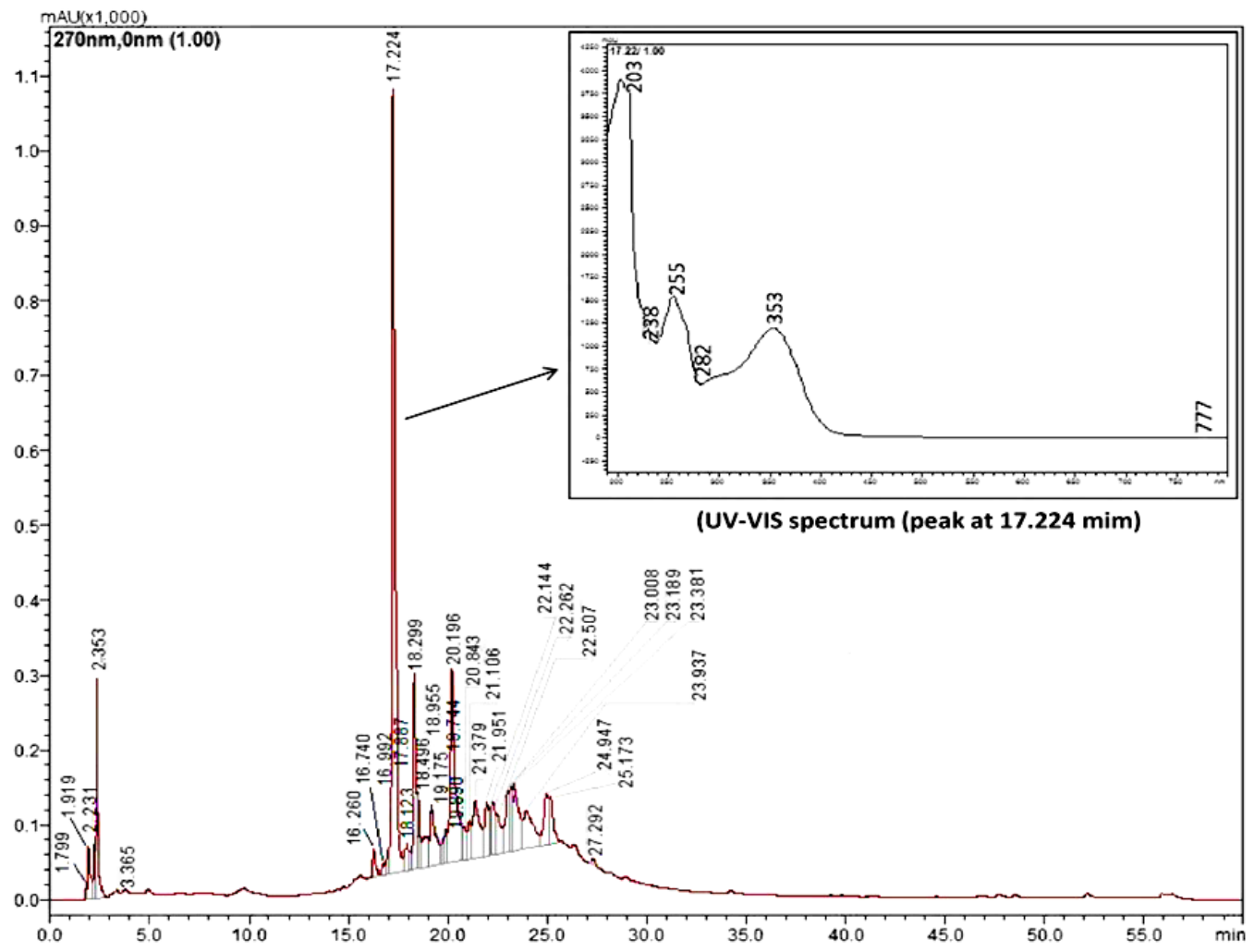

Figure 1 - HPLC-DAD chromatogram at $270 \mathrm{~nm}$ of ethanolic extract of Senna rugosa and UV-Vis spectrum of the major component identified in HPLC method. 
standards were chosen for elution in HPLC-DAD under the same conditions as those in the crude extract. Considering the results of studies of other researchers (Barbosa et al. 2004) and the common anthraquinones and flavonoids in this genus (Baez et al. 1999; Barbosa et al. 2004), the standards rutin, emodin and aloe-emodin (Sigma-Aldrich ${ }^{\circledR}$ Sto Louis, MO, USA) had their retention times and UV-Vis spectra compared to the crude extract chromatogram. The analysis of the results of the standards indicates that the major peak is the rutin (flavonol glycoside). The comparison of the data did not reveal the presence of emodin and aloe-emodin in the crude extract. This result may be evidence of a low concentration of anthraquinones and could be evidenced by more sensitive techniques.
Analysis of fractions by GC-MS and ESI-MS

The GC-MS analysis of the ethanolic extract led to the identification of 8 compounds including leaf waxes (octacosane, decane and heptacosane) fatty alcohol (phytol), aromatic hydrocarbons (ethylbenzene, m-xylene and p-xylene) (Fig. 2) and 1-Methylpentyl Hydroperoxide (Tab. 2).

Acidic constituents' analysis in the ESI-MS (negative mode) showed the presence of peaks traditionally associated with phenolic compounds (Tab. 3; Figs. 3; 4). However, the full identification of compounds requires more detailed studies. The peak at $416 / 417$ confirms the positive results for anthraquinones (Barbaloin/isobarbaloin) given by the preliminary phytochemical analysis (Tab. 3).

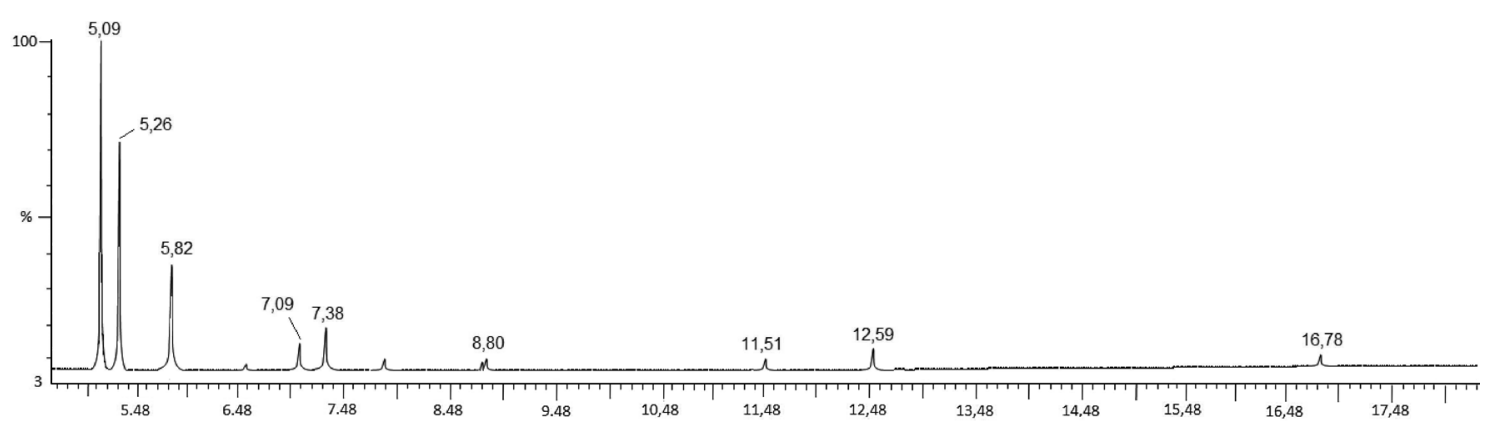

Figure 2 - Chromatogram with most prominent peaks of ethylbenzene, $m$-xylene and $p$-xylene in GC-MS chromatogram of the $2^{\text {nd }}$ fraction of ethanolic extract of Senna rugosa leaf. For try to relate the phytoconstituents to the retention time, please see Table $3\left(\right.$ sample $\mathrm{N}^{\circ}$ 2).

Table 2 - Identified peaks in fractions by GC-MS of Senna rugosa leaf ethanolic extract.

\begin{tabular}{llccc}
\hline${\text { Sample } \mathbf{N}^{\mathbf{0}}}$ & Compound & $\begin{array}{c}\text { Retention Time } \\
(\mathbf{m i n})\end{array}$ & $\begin{array}{c}\text { Molecular } \\
\text { weight }\end{array}$ & Major peaks \\
\hline 1. & Octacosane & 32.98 & 394.76 & $57,43,71,85$ \\
2. & 5.09 & 106.16 & 91,106 \\
& Ethylbenzene & 5.26 & 106.16 & 91,106 \\
& $m$-Xylene & 5.82 & 106.16 & 91,106 \\
& $p$-Xylene & 7.38 & 118.17 & 43,41 \\
& 1-Methylpentyl Hydroperoxide & 11.51 & 142.29 & 43,57 \\
& Decane & 33.89 & 380.73 & $57,43,71,85$ \\
& Heptacosane & 31.11 & 296.54 & $71,43,57,81$ \\
\hline
\end{tabular}


Table 3 - Analysis of $8^{\text {th }}$ and $9^{\text {th }}$ fractions of Senna rugosa leaves extract by ESI-MS of low resolution (Negative Mode).

\begin{tabular}{lcll}
\hline Fraction & {$[\mathbf{M}-\mathbf{H}]^{-}$} & M.W & Suggested Compounds \\
\hline $8^{\text {th }}$ & 302 & \multicolumn{1}{c}{ - } & Unknown \\
$417 / 416$ & 418.39 & Barbaloin / isobarbaloin \\
543 & 544.14 & Proanthocyanidin (E)afzelechin-(E)afzelechin or \\
& 544.50 & Diferuloylquinic acid (isomers) \\
657 & 658.56 & Dihydromyricetin diglucoside \\
769 & 770.78 & Proanthocyanidin trimer (prodistenidin C) \\
883 & 884.7 & P2 analogs (EGCG* degradation) \\
$9^{\text {th }}$ & - & Proanthocyanidin oligomers \\
249 & 250.29 & Caffeoyl putrescine \\
255 & 256.25 & Emodin anthrone / Aloe-emodin anthrone \\
379 & - & Unknown \\
403 & 404.41 & Pinocembrin derivative \\
515 & 516.45 & Dicaffeoylquinic acid isomers \\
\hline
\end{tabular}

$*$ = epigallocatechin-3-gallate

Moreover, Barbaloin/isobarbaloin and Emodin anthrone/Aloe-emodin anthrone, are according to the class of substances common to the genus. Although anthraquinone derivatives have not been shown in HPLC-DAD, this fact indicates an increase in the concentrations of these compounds provided by the fractioning step, associated with a more sensitive characterization method ESI-MS, allowing the identification in this step. The evidence of anthraquinones generates the possibility of future research on the cathartic action of fractions of the Senna rugosa leaf extract. Otherwise, the identification of rutin in HPLC-DAD and non-detection in ESI-MS indicate the loss of the compound throughout the fractionation step.

\section{Biological results}

The leaf extract demonstrated relative antimicrobial activity against Staphylococcus aureus (Gram-positive species) with MIC of 500 $\mu \mathrm{g} / \mathrm{mL}$ and Pseudomonas aeruginosa (Gramnegative species) with MIC of $250 \mu \mathrm{g} / \mathrm{mL}$. The polyphenols compounds present in various plant species are well documented to have microbial activities against many pathogenic bacteria (Scalbert 1991; Cowan 1999). The total phenolic compound contents in Senna rugosa ethanolic leaf extract and the rich phenolic compounds content in the $8^{\text {th }}$ and $9^{\text {th }}$ fractions (Tab. 1) provides some inkling for the action of polyphenols on antimicrobial activity demonstrated.

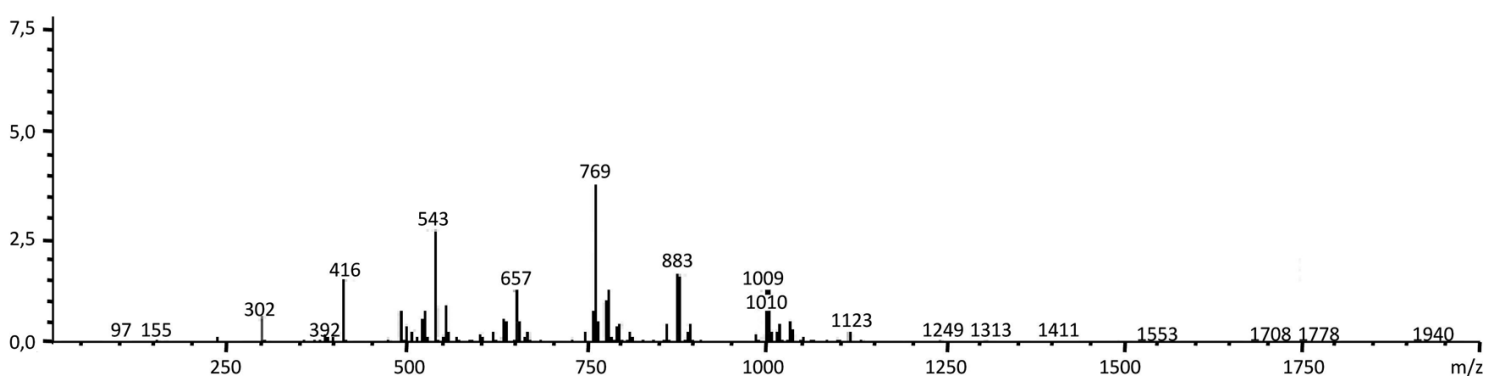

Figure 3 - Mass spectrum (ESI-MS) of $8^{\text {th }}$ fraction of Senna rugosa leaf extract in negative mode. 


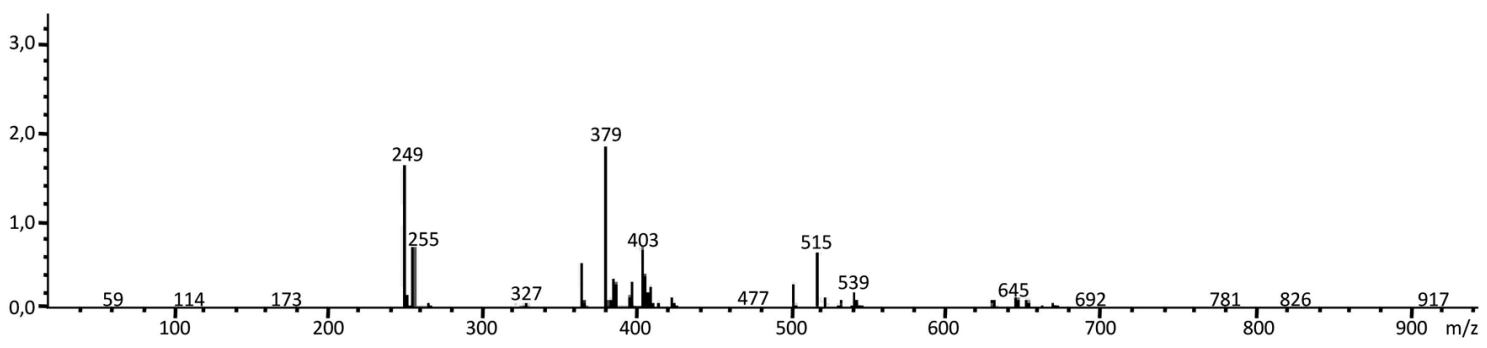

Figure 4 - Mass spectrum (ESI-MS) of $9^{\text {th }}$ fraction of Senna rugosa leaf extract in negative mode.

Activity against $S$. aureus was also observed by Ederhardt (2012) which demonstrated a bacteriostatic effect corroborating the data obtained in our studies. Anthraquinones (Chrysophanol), flavonoids (kaempferol) and terpenoids ( $\beta$-sitosterol) obtained from Senna reticulata (Willd.) H.S. Irwin \& Barneby (1982: 35) were associated to antimicrobial activity (Kataoka et al. 2001; Singh \& Singh 2003; Garcia-Sosa et al. 2006; Santos et al. 2008). All these secondary metabolite classes were also observed in the phytochemistry screening of leaf extract of Senna rugosa. The crude extract was tested against six pathogenic fungi and effective antifungal activities were observed against $C$. famata (CIM of $62.5 \mu \mathrm{g} / \mathrm{mL}$ ) C. krusei $(62.5 \mu \mathrm{g} / \mathrm{mL})$ and C. tropicalis (CIM de $125 \mu \mathrm{g} / \mathrm{mL})$, in all cases with fungicidal action. The antifungal activity has already been associated to other species belonged Senna genus, for example,
S. alata (L.) Roxb. (1832: 349) (Sule et al. 2010) and S. obtsufolia (L.) H.S. Irwin \& Barneby (1831: 252) (Doughari et al. 2008). Anthraquinones isolated from Senna alata showed activity against several fungi species (Wuthi-Udomlert et al. 2010) and this metabolic were also observed in the Senna rugosa ethanol leaf extract. Several species of the genus Senna were not also active against Candida albicans including leaf ethanolic extracts of Senna podocarpa (Guill. \& Perr.) Lock (1988: 340) and Senna tora (L.) Roxb. (1832: 340) and Senna spectalbilis (DC.) H.S. Irwin \& Barneby (1962: 600) (Chukeatirote et al. 2007; Ogundare 2009).

The trypanocidal assay not showed activity against neither $T$. cruzi strains as summarized in Figure 5. For anti-leishmanial activity was observed a weak effect of the extract on the concentration of 1,000 and $500 \mu \mathrm{g} / \mathrm{mL}$ for the strain M2269 and only of $1000 \mu \mathrm{g} / \mathrm{mL}$ for the strain BH46 (Fig. 6).

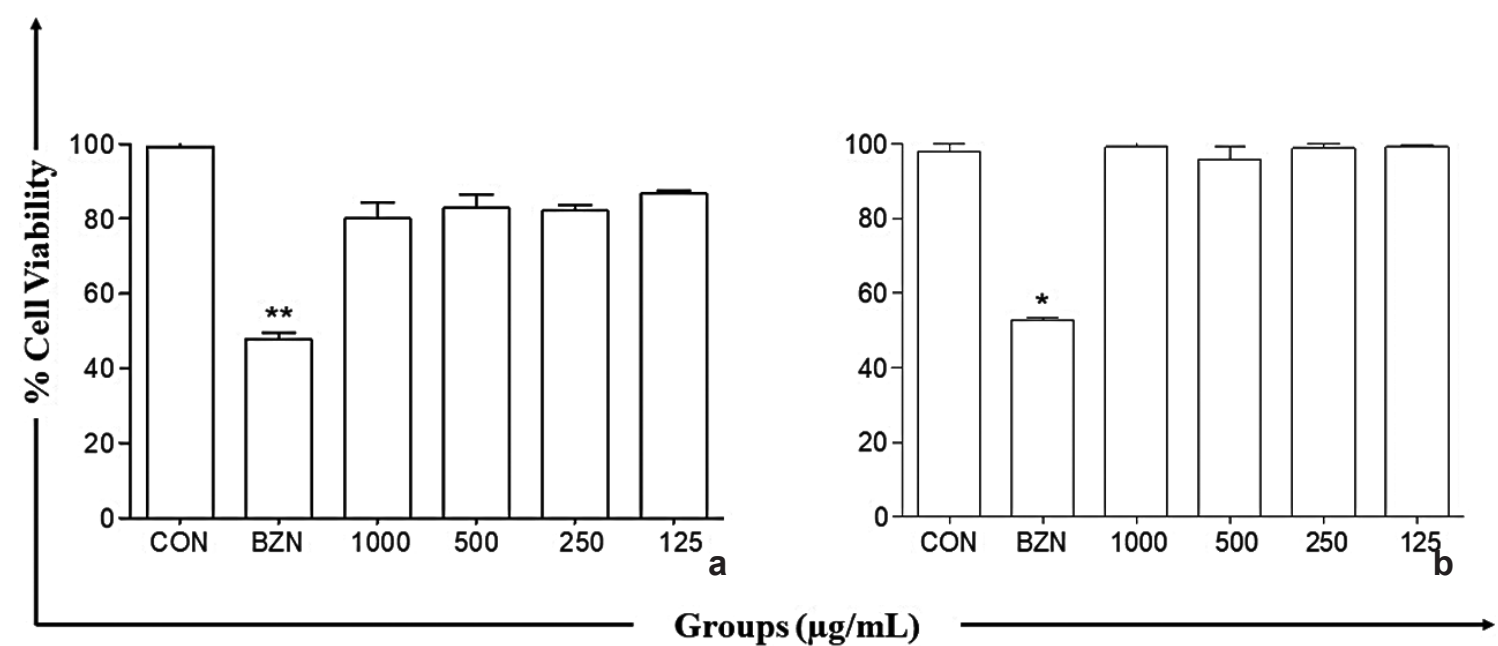

Figure 5 - a-b. Results obtained from in vitro assay of Senna rugosa leaf extract against epimastigotes form from Trypanosoma cruzi-a. Y strain; b. Colombian strain. The results were expressed as the average percentage of viability \pm standard deviation of three assays. Assays were carried out in triplicate and compared with results obtained for the control of cell $(\mathrm{CON}) .{ }^{*} \mathrm{p}<0.05$ and $* * \mathrm{p}<0.01$. BZN- benznidazole was used as standard drug. 

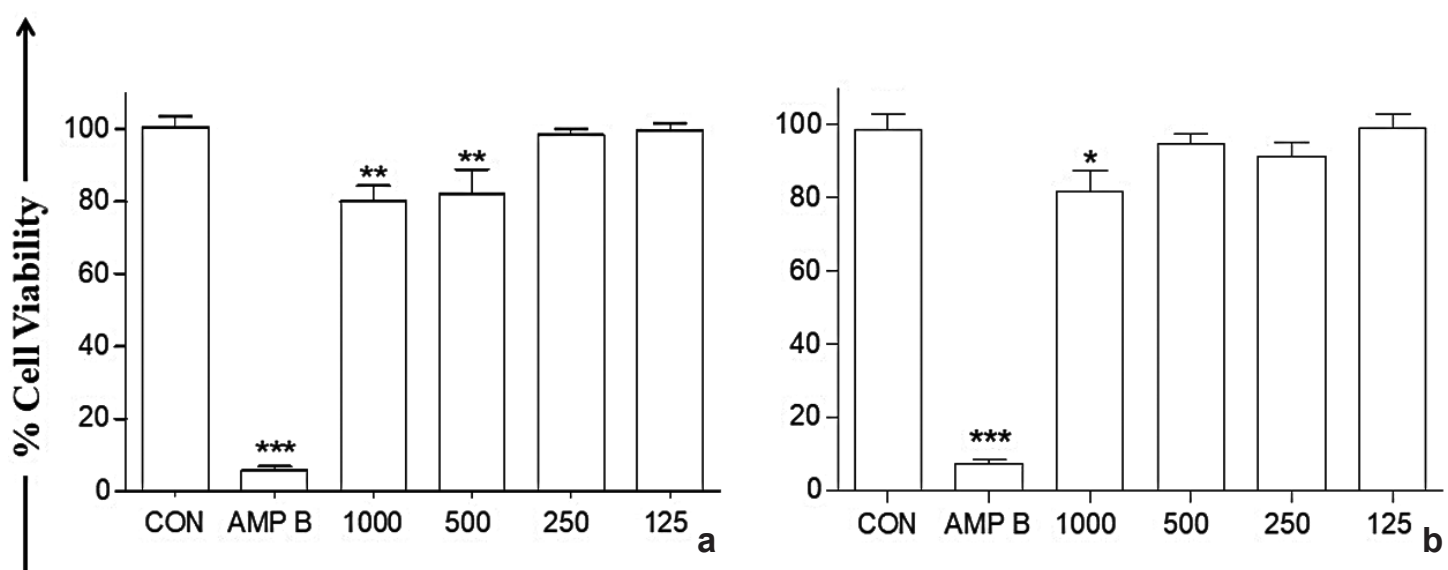

Groups $(\mu \mathrm{g} / \mathrm{mL})$

Figure 6 - a-b. Results obtained in vitro activity assay of Senna rugosa ethanolic leaf extract against promastigotes - a. from Leishmania (Leishmania) amazonensis amazonensis M2269; b. from Leishmania (Leishmania) infantum $\mathrm{BH} 46$. The results were expressed as the average percentage of cell viability \pm standard deviation of three assays. Assays were carried out in triplicate and compared with results obtained for the control of cell $(\mathrm{CON}) .{ }^{*} \mathrm{p}<0.05$; $* * \mathrm{p}<0.01$ and $* * * \mathrm{p}<0.001$. AMP B-Amphotericin B was used as standard drug.

Antitumoral activity evaluation of Senna rugosa ethanolic leaf extract against MDA-MB-231 cells showed significant activity at concentrations $1,000-250 \mu \mathrm{g} / \mathrm{mL}$ (cell viability reduction ranging from $87.37 \%$ to $14.91 \%$ and $\mathrm{IC}_{50}=607.9 \mu \mathrm{g} / \mathrm{mL}$ ) showed in the Figure 7. Given the efficacy relative to paclitaxel $(100 \%$ efficiency and percentage of cell death $85.66 \%$ ), was found greater effectiveness in the highest tested concentration corresponding to $111.38 \%$. Potential antitumoral activity were

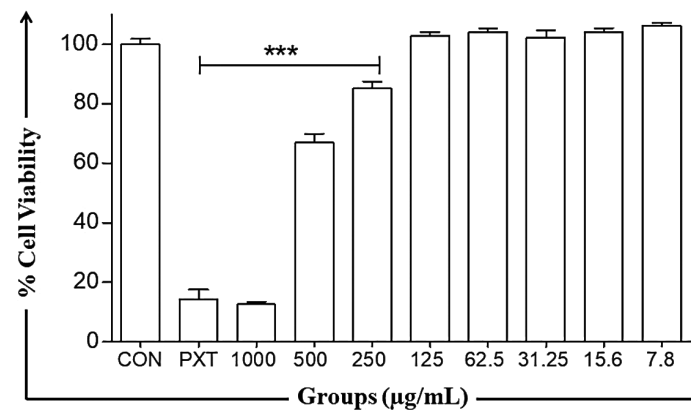

Figure 7 - Results obtained from in vitro assay for antitumoral activity assay of Senna rugosa ethanolic leaf extract against MDA-MB-231 cells. The results were expressed as the average percentage of viability \pm standard deviation of three assays. Assays were carried out in triplicate and compared with results obtained for the control of cell $(\mathrm{CON})$. *** $\mathrm{p}<0.001$. PXT $=$ paclitaxel used as standard drug. observed in other species of Senna genus, for example Senna alata (Olarte et al. 2013); Senna tora (Zhao et al. 2013); Senna italica Mill. (1768: 8(2)) (Masoko et al. 2009), Senna gardneri (Benth.) H.S. Irwin \& Barneby (1982: 192), Senna splendida (Vogel) H.S. Irwin \& Barneby (1982: 190) (Silva et al. 2014) and Senna occidentalis (L.) Link (1829: 140) (Essien et al. 2011). Considering the antitumoral activity despite the good efficiency by Senna rugosa leaf extract the selectivity index (SI) was only 0.79 . Because the $S$. rugosa extract showed high toxicity to the murine fibroblast cells (L929) with $\mathrm{CC}_{50}$ of $480.8 \mu \mathrm{g} / \mathrm{mL}$ and leading to viability reduction of 53.9 and $14.65 \%$ for the concentration of 1,000 and $31.25 \mu \mathrm{g} / \mathrm{mL}$ respectively (Fig. 8).

Toxicity was observed in other species belonged to Senna genus evaluated in vivo model (Yagi et al. 1998; Momin et al. 2012). Senna occidentalis was described as toxic species due to the presence of anthraquinone which causes the uncoupling of mitochondrial oxidative phosphorylation (Yadav et al. 2010). This secondary metabolic was also observed in the $S$. rugosa leaf. In the same way, flavonoids have been observed and associated with cell toxicity in other species (Levy \& Carley 2012; Silva et al. 2014).

\section{Conclusions}

In this present study, we performed the chemical and biological profile of Senna rugosa ethanolic leaf extract. The data obtained in our 


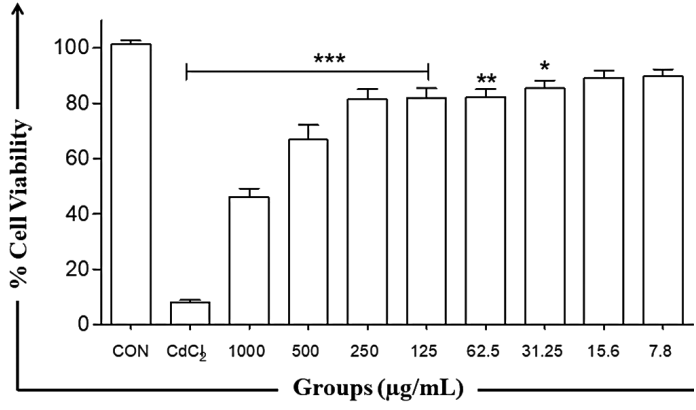

Figure 8-Results obtained from in vitro cytotoxicity assay of Senna rugosa leaf extract against cellular viability of mouse fibroblast cells (L929). The results were expressed as the average percentage of viability \pm standard deviation of three assays. Assays were carried out in triplicate and compared with results obtained for the control of cell $(\mathrm{CON}){ }^{*} \mathrm{p}<0.05 ; * * \mathrm{p}<0.01$ and $* * * \mathrm{p}<0.001 . \mathrm{CdCl}_{2}=$ cadmium chloride used as cell death control.

research show that $S$. rugosa showed a chemical profile rich in phenolic compounds, such as rutin, anthraquinones and anthrones derivatives. And these compounds have shown diverse pharmacological activities justifying further studies, among them the cathartic function that is historically associated with the genus. For antitrypanosomatids was observed only a weak against M2269 strain and BH46 strains of Leishmania sp. And although it has been observed a high antitumoral activity a high cytotoxicity in fibroblast cells (L929) was also observed, and the SI was very low (0.79). Considering the antimicrobial activity, were observed particularly promising activity against the species Staphylococcus aureus and Pseudomonas aeruginosa (bacteria species) and Candida famata, Candida krusei and Candida tropicalis (fungi species) with strong possibility that these activities could also be linked to the presence of phenolic compounds as observed for other species of Senna genus.

\section{Acknowledgments}

This research was supported by the State of Minas Gerais Research Support Foundation (FAPEMIG - APQ-01626-13) and National Council for Scientific and Technological Development (CNPq - Process 449401/2014-6). The authors are grateful to FINEP, CAPES and special thanks to Cássia Michelle Cabral for the assistance identifying the plant. We are also grateful to
LANAGRO/MAPA, Thiago Freitas Borgatti, IMA/LQA, Herlaine de Sousa for granting the reagents and materials and Integrated Center for Postgraduate Studies and Research in Health at the UFVJM, Diamantina, MG and Department of Pharmacy for providing equipment and technical support for experiments.

\section{References}

Abegaz BM, Bezabeh M, Alemayehu G \& Duddeck H (1994) Anthraquinones from Senna multiglandulosa. Phytochemistry 35: 465-468.

Adams RP (2007) Identification of essential oil components by gas chromatography-mass spectroscopy. $4^{\text {nd }}$ ed. Allured Publishing Corporation, Carol Stream, Illinois. Pp. 55-787.

Alemayehu G, Abegaz BM, Snatzke G \& Duddeck H (1989) Quinones of Senna Didymobotrya. Bulletin of the Chemical Society of Ethiopia 3: 37-40.

Almagboul AZ, Bashir AK, Farouk A \& Salih AM (1985) Antimicrobial activity of certain Sudanese plants used in folkloric medicine. Screening for antibacterial activity. Fitoterapia 56: 331-337.

Artizzu N, Bonsignore L, Cottiglia F \& Loy G (1995) Studies of the diuretic and antimicrobial activity of Cynodon dactylon essencial oil. Fitoterapia 66: 174-175.

Azevedo LP, Faria TA, Pessanha FF, Araujo MF \& Lemos GS (2014) Phytochemical screening and antioxidant activity of Costus spicatus (Jacq.) Sw. Revista Brasileira de Plantas Medicinais 16: 209-215.

Baez DA, Vallejo LGZ \& Jimenez-Estrada M (1999) Phytochemical studies on Senna skinneri and Senna wislizeni. Natural Product Research 13: 223-228.

Balasundram N, Sundram K \& Samman S (2006) Phenolic compounds in plants and agri-industrial by-products: antioxidant activity, occurrence, and potential uses. Food Chemistry 99: 191-203.

Barbosa FG, Oliveira MCF, Braz-Filho R \& Silveira ER (2004) Anthraquinones and naphthopyrones from Senna rugosa. Biochemical Systematics and Ecology 32: 363-365.

Bastos DH, Saldanha LA, Catharino RR, Sawaya AC, Cunha IB, Carvalho PO \& Eberlin MN (2007) Phenolic antioxidants identified by ESI-MS from yerba mate (Ilex paraguariensis) and green tea (Camelia sinensis) extract. Molecules 12: 423-432.

Beckman CH (2000) Phenolic-storing cells: keys to programmed cell death and periderm formation in wilt disease resistance and in general defense responses in plants? Physiological and Molecular Plant Pathology 57: 101-110.

BFG - The Brazil Flora Group (2018) Brazilian Flora 2020: innovation and collaboration to meet Target 1 of the Global Strategy for Plant Conservation (GSPC). Rodriguésia 69: 1513-1527.

Bhalodia NR \& Shukla VJ (2011) Antibacterial and 
antifungal activities from leaf extracts of Cassia fistula L. An ethnomedicinal plant. Journal of Advanced Pharmaceutical Technology \& Research 2: 104-109.

Bruneton J (2001) Farmacognosia: fitoquímica de plantas medicinais. $2^{\text {a }}$ ed. Acribia, Zaragoza. Pp. 405-428.

Casellas JM (2011) Antibacterial drug resistance in Latin America: consequences for infectious disease control. Revista Panamericana de Salud Pública 30: 519-528.

Chukeatirote E, HanpattanakitP, Kaprom A \& Tovaranonte $\mathrm{J}$ (2007) Antimicrobial activity of Senna spectabilis and S. tora. Journal of Plant Sciences 2: 123-126.

CLSI - Clinical and Laboratory Standards Institute (2012) Methods for dilution antimicrobial susceptibility tests for bacteria that grow aerobically. Vol. 32. $9^{\text {a }}$ ed. Document M07-A9. Clinical and Laboratory Standards Institute, Wayne. Pp. 12-32. [ISBN 1-56238-784-7].

CLSI - Clinical and Laboratory Standards Institute (2002a) Reference method for broth dilution testing for a determination of sensitivity to yeast antifungal therapy. Vol. 22. 2a ed. Document M27-A2. Clinical and Laboratory Standards Institute, Wayne. Pp. 1731. [ISBN 1-56238-469-4].

CLSI - Clinical and Laboratory Standards Institute (2002b) Reference method for dilution testing in broth for the determination of sensitivity to antifungal therapy of filamentous fungi. Vol. 22 . Documento M38-A. Clinical and Laboratory Standards Institute, Wayne. Pp. 17-31. [ISBN 1-56238-470-8].

Cowan MM (1999) Plants products as antimicrobial agents. Clinical Microbiology Reviews 12: 5645682.

Dantas MM \& Silva MJ (2013) The genus Senna Mill. (Leguminosae, Caesalpinioideae, Cassieae) in Parque Estadual da Serra Dourada, Goiás state, Brazil. Hoehnea 40: 99-113.

Dave H \& Ledwani L (2012) A review on anthraquinones isolated from Cassia species and their applications. Indian Journal of Natural Products and Resources 3: 291-319.

Doughari JH, El-Mahmood AM \& Tyoyina I (2008) Antimicrobial activity of leaf extract of Senna obtusifolia (L). African Journal of Pharmacy and Pharmacology 2: 7-13.

Eberhardt GN (2012) Antioxidant, antidiabetic and antimicrobial activity of Senna rugosa (G. Don) H.S. Irwin and Barneby (1982) and Senna velutina (Vogel) H.S. Irwin and Barneby (1982). Tese de Mestrado. Universidade Federal da Grande Dourados, Dourados. 76p.

El Sayed AM, Ezzat SM, El Naggar MM \& El Hawary SS (2016) In vivo diabetic wound healing effect and HPLC-DAD-ESI-MS/MS profiling of the methanol extract of eight Aloe species. Revista Brasileira de Farmacognosia 26: 352-362.
Essien EE, Walker TM, Ogunwande IA, Bansal A, Setzer WN \& Ekundayo O (2011) Volatile constituents, antimicrobial and cytotoxicity potentials of three Senna species from Nigeria. Journal of Essential Oil Bearing Plants 14: 722-730.

Falcão SI, Vilas-Boas M, Estevinho LM, Barros C, Domingues MR \& Cardoso SM (2010) Phenolic characterization of Northeast Portuguese propolis: usual and unusual compounds. Analytical and Bioanalytical Chemistry 396: 887-897.

Farias DF, Cavalheiro MG, Viana MP, Queiroz VA, Rocha-Bezerra LB, Vasconcelos IM, Morais SM \& Carvalho AU (2010) Water extract of Brazilian leguminous seeds as rich sources of larvicidal compounds against Aedes aegypti L. Anais da Academia Brasileira de Ciências 82: 585-594.

Filardi LS \& Brener Z (1987) Susceptibility and natural resistance of Trypanosoma cruzi strains to drugs used clinically in Chagas disease. Transactions of the Royal Society of Tropical Medicine and Hygiene 81: 755-759.

Garcia-Sosa K, Villareal-Alvarez N, Lubben P \& Pena-Rodriguez LM (2006) Chrysophanol, an antimicrobial anthraquinone from the root extract of Colubrina greggii. Journal of the Mexican Chemical Society 50: 76-78.

Gill M \& Morgan PM (2001) New fungal anthraquinones. Arkivoc 7: 145-156.

Hamed AI, Al-Ayed AS, Moldoch J, Piacente S, Oleszek W \& Stochmal A (2014) Profiles analysis of proanthocyanidins in the argun nut (Medemia argun an ancient Egyptianpalm) by LC-ESI-MS/MS. Journal of Mass Spectrometry 49: 306-315.

Hendrickx S, Guerin PJ, Caljon G, Croft SL \& Maes L (2018) Evaluating drug resistance in visceral leishmaniasis: the challenges. Parasitology 145: 453-463.

Kataoka M, Hirata K, Kunikata T, Ushio S, Iwaki K, Ohashi K, Ikeda M \& Kurimoto M (2001) Antibacterial action of tryptanthrin and kaempferol, isolated from the indigo plant (Polygonum tinctorium Lour.), against Helicobacter pylori-infected Mongolian gerbils. Journal of Gastroenterology 36 : 5-9.

Kratz JM (2019) Drug discovery for chagas disease: a viewpoint. Acta Tropica 198: 105-107.

Kunz AN \& Brook I (2010) Emerging resistant Gramnegative aerobic bacilli in hospital-acquired infections. Chemotherapy 56: 492-500.

Levy AS \& Carley SK (2012) Cytotoxic activity of hexane extract of Psidium Guajava L (Myrtaceae) and Cassia Alata L (Caesalpineaceae) in Kasumi-1 and OV2008 cancer cell lines. Tropical Journal of Pharmaceutical Research 11: 201-207.

Li SF, Di YT, Luo RH, Zheng YT, Wang YH, Fang X, Zhang Y, Li L, He HP, Li SL \& Hao XJ (2012) Cycloartane Triterpenoids from Cassia occidentalis. Planta Medica 78: 821-827. 
Luisi FV, Petrillli AS, Tanaka C \& Caran EM (2006) Contribution to the treatment of nausea and emesis induced by chemotherapy in children and adolescents with osteosarcoma. São Paulo Medical Journal 124: 61-65.

Masoko P, Gololo SS, Mokgotho MP, Eloff JN, Howard RI \& Mampuru LJ (2009) Evaluation of the antioxidant, antibacterial, and antiproliferative activities of the acetone extract of the roots of Senna italica (Fabaceae). African Journal of Traditional, Complementary and Alternative Medicines 7: 138-148.

Momin MM, Bellah SF, Afrose A, Urmi KF, Hamid K \& Rana MS (2012) Phytochemical screening and cytotoxicity potential of ethanolic extract of Senna siamea leaves. Journal of Pharmaceutical Sciences and Research 4: 1877-1879.

Mohammed MMD (2016) Structure antimutagenicity relationship of Anthraquinones. Natural Products Chemistry and Research 4: 228.

Mosmann T (1983) Rapid colorimetric assay for cellular growth and survival: application to proliferation and cytotoxicity assays. Journal of immunological methods 65: 55-63.

Muelas-Serrano S, Nogal JJ, Martínez-Díaz RA, Escario JA, Martínez-Fernández AR \& Gómez-Barrio A (2000) In vitro screening of American plant extract on Trypanosoma cruzi and Trichomas vaginalis. Journal of Ethnopharmacology 71: 101-107.

Nakamura HM, Caldeira SM \& Avila MAG (2013) Incidence of fungic infections in surgery patients: a retrospective approach. Revista SOBECC 18: 49-58.

Navarre DA, Pillay SS, Shakya R \& Holden MJ (2011) HPLC profiling of phenolics in diverse potato genotypes. Foodchemistry 127: 34-41.

Newman DJ \& Cragg GM (2016) Natural products as sources of new drugs from 1981 to 2014. Journal of Natural Products 79: 629-661.

Ogundare OA (2009) The antimicrobial pattern and phytochemical properties of the leaf extract of Senna podocarpa. African Journal of Microbiology Research 3: 400-406.

Olarte EI, Herrera AA, Villaseñor IM \& Jacinto SD (2013) In vitro antitumor properties of an isolate from leaves of Cassia alata L. Jornal do Pacífico Asiático de Prevenção 14: 3191-3196.

Oliveira AC \& Silva RS (2008) Health care challenges facing bacterial resistance: a review. Revista Eletrônica de Enfermagem 10: 189-197.

Rodrigues VG \& Carvalho DA (2001) Levantamento etnobotânico de plantas medicinais no domínio do cerrado na região do Alto Rio Grande, Minas Gerais. Ciência e Agrotecnologia 25: 102-123.

Sundar S \& Chakravarty J (2015) An update on pharmacotherapy for leishmaniasis. Expert Opin Pharmacother 16: 237-252.

Sahu M, Vermaand D \& Harris KK (2014) Phytochemical analysis of the leaf, stem and seed extract of Cajanus cajan L (Dicotyledoneae: Fabaceae). Journal of Pharmacy and Pharmaceutical Sciences 3: 694-733.

Sakulpanich A \& Gritsanapan W (2008) Extraction method for hight contend of anthraquinones from Cassia fistula pods. Journal of Health Research 22: 167-172.

Sang S, Yang I, Buckley B, Ho CT \& Yang CS (2007) Autoxidativequinone formation in vitro and metabolite formation in vivo from tea polyphenol (-)-epigallocatechin-3-gallate: studied by real-time mass spectrometry combined with tandem mass ion mapping. Free Radical Biology and Medicine 43: 362-371.

Santos RN, Silva MV \& Braz-Filho R (2008) Chemical constituents isolated from the wood of Senna reticulata Willd. Química Nova 31: 1979-1981.

Scalbert A (1991) Antimicrobial properties of tannins. Phytochemistry 30: 3875-3883.

Schmeda-Hirschmann G, Quispe C \& González B (2015) Phenolic profiling of the South American "baylahuen" tea (Haplopappus spp., Asteraceae) by HPLC-DAD-ESI-MS. Molecules 20: 913-928.

Sebaugh JL (2011) Guidelines for accurate $\mathrm{EC}_{50} / \mathrm{IC}_{50}$ estimation. Pharmaceutical Statistics 10: 128-134.

Silva JA, Monteiro JA, Ferreira EB, Fernandes MB, Pessoa CO, Sampaio CG \& Silva MV (2014) Total phenolic contente, antioxidant and anticancer activities of four species of Senna Mill. From northeast Brazil. International Journal of Pharmacy and Pharmaceutical Sciences 6: 199-202.

Silva RF (2010) Chapter 8: fungal infections in immunocompromised patients. Jornal Brasileiro de Pneumologia 36: 142-147.

Simões CO, Sckemkel EP, Gosmann G, Mello JP, Mentz LA \& Petrovick PR (2007) Farmacognosia: da planta ao medicamento. $6^{\mathrm{a}}$ ed. UFSC, Florianópolis. Pp. 229-45.

Singh B \& Singh S (2003) Antimicrobial activity of terpenoids from Trichodesm a amplexicaule Roth. Phytotherapy Research 17: 814-6.

Singleton VL, Joseph A \& Rossi J (1965) Colorimetry of total phenolics with phosphomolibdicphosphotungstic acid reagents. American Journal of Enology and Viticulture 16: 144-149.

Spindola KC, Simas NK, Salles TS, de Meneses MD, Sato A, Ferreira D, Romão W \& Kuster RM (2014) Anti-Mayaro virus activity of Cassia australis extracts (Fabaceae, Leguminosae). Parasites \& Vectors 7:537.

Sule WF, Okonko IO, Joseph TA, Ojezele MO, Nwanze JC, Alli JÁ \& Adewale OG (2010) In vitro antifungal activity of Senna alata Linn. crude leaf extract. Research Journal of Biological Sciences 5: 275-284.

Thavamani BS, Mathew M \& Dhanabal SP (2014) Anticancer activity of Cissampelos pareira 
against Dalton's lymphoma ascites bearing mice. Pharmacognosy Magazine 10: 200-206.

Tsao R (2010) Chemistry and biochemistry of dietary polyphenols. Nutrients 2: 1231-1246.

WHO - World Health Organization (2017) Fourth WHO report on neglected tropical diseases: integrating neglected tropical diseases into global health and development. Available at $<$ https://www.who.int/ neglected_diseases/resources/9789241565448/ en/>. Access on 19 September 2019.

WHO - World Health Organization (2018a) Leishmaniasis fact sheet. Available at $<$ http://www.whoint/en/ newsroom/fact-sheets/detail/leishmaniasis $>$. Access on 19 September 2019.

WHO - World Health Organization (2018b) Noncommunicable diseases country profiles. Available at <https://www.who.int/nmh/ publications/ncd-profiles-2018/en//>. Access on 19 September 2019.
Ventola C (2015) The antibiotic resistance crisis. Pharmacy and Therapeutics 40: 277-283.

Wuthi-Udomlert M, Kupittayanant P \& Gritsanapan W (2010) In vitro evaluation of antifungal activity of anthraquinone derivatives of Senna alata. Journal of Health Research 24: 117-122.

Yadav JP, Arya V, Yadav S, Panghal M, Kumar S \& Dhankhar S (2010) Cassia occidentalis L.: a review on its ethnobotany, phytochemical and pharmacological profile. Fitoterapia 81: 223-230.

Yagi SM, Tigani SE \& Adam SEI (1998) Toxicity of Senna obtusifolia fresh and fermented leaves (kawal), Senna alata leaves and some products from Senna alata on rats. Phytotherapy Research 12: 324-330.

Zhao X, Wang Q, Qian Y \& Pang L (2013) Cassia tora L. (Jue-ming-zi) has anticancer activity in TCA 8113 cells in vitro and exerts anti-metastatic effects in vivo. Oncology Letters 5: 1036-1042. 